\title{
THE EFFECT OF IRRIGATION AND NITROGEN TOP- DRESSING PATTERN ON YIELD AND GROWTH OF SUNFLOWER
}

\author{
Madani, A. , Vazin, F. and Haghighi, Z.
}

Islamic Azad University, Gonabad Branch, Gonabad, Iran

Received: September 20, 2013 Accepted: December 05, 2013

\section{SUMMARY}

In order to study the effect of irrigation $\left(\mathrm{I}_{0}\right.$ : optimum irrigation, $\mathrm{I}_{\mathrm{V}}$ and $\mathrm{I}_{\mathrm{R}}$ : water stress during vegetative and reproductive stages, respectively) and nitrogen $\left(\mathrm{N}_{1}: 25 \%\right.$ at planting, $50 \%$ at eight-leaf stage and $25 \%$ at head appearance; $\mathrm{N}_{2}: 50 \%$ at eight leaf stage and $50 \%$ at head appearance; $\mathrm{N}_{3}: 50 \%$ planting and $50 \%$ head appearance) on yield and growth of sunflower, a split-plot experiment was conducted in 2011 and 2012. Average cross years, $I_{V}$ and $I_{R}$ caused a significant reduction of final dry leaf (20.4 and $34.5 \%)$, stem ( 40.5 and $45.7 \%$ ) and total weight (25.9 and $28.0 \%$ ) and also a significant reduction of the grain yield as much as $14.8 \%$ and $13.3 \%$ in comparison to $\mathrm{I}_{0}$. $\mathrm{N}_{1}$ caused a significant 25 and $14 \%$ reduction of the leaf area index in comparison to $\mathrm{N}_{3}$ and $\mathrm{N}_{2}$; however, the grain yield was not significantly different in $\mathrm{N}_{3}$ and $\mathrm{N}_{2}$ in both years. In $\mathrm{I}_{0}, \mathrm{~N}_{3}$ caused a significant $34.8 \%$ increase of final dry weight of the leaf and an insignificant increase of dry weight of stem and the total weight as much as $30.9 \%$ and $16.3 \%$, respectively and also a significant $16.4 \%$ reduction of the grain yield in comparison to $\mathrm{N}_{2}$. On the whole, $\mathrm{N}_{2}$ treatment in different irrigation regime caused a higher grain yield in comparison to $\mathrm{N}_{1}$ and $\mathrm{N}_{3}$, but $\mathrm{N}_{3}$ treatment in $\mathrm{I}_{0}$, and $\mathrm{N}_{1}$ in $\mathrm{I}_{\mathrm{V}}$ and $\mathrm{I}_{\mathrm{R}}$ reduced the grain yield.

\section{Key words: dry matter, irrigation, grain yield, nitrogen top-dressing, sunflower}

\section{INTRODUCTION}

Sunflower is relatively tolerant to water stress. Pejić et al. (2009) reported that no significant differences in yield of sunflower were observed between irrigated treatment, in which irrigation was used when soil moisture levels dropped to 60$65 \%$ of FC (field capacity), and a non-irrigated control treatment when irrigation was not applied from flowering to maturity. However, Hussain et al. (2012) reported that growth and yield of sunflower were severely reduced by limited irrigation, when irrigation was withheld at the bud initiation. These examining growth indices in

* Corresponding author: e-mail: madani_ahad@yahoo.com 
analyzing the factors influencing sunflower yield are of great importance (Parmar and Chanda, 2002). By studying the production and partitioning of dry matter and growth indices, it is possible to interpret the reaction of sunflower towards irrigation and nitrogen and their interaction during the growth and also to get to know the plant growth trend better in every region (Mojaddam et al., 2012). Considering the optimum amount of nitrogen and its top-dressing pattern during the growth season in proportion to irrigation regime and the interaction between these two factors, it has a particular importance in minimizing the environment pollution, reducing the costs, and achieving the optimum yield (Jalalian et al., 2012). It seems that true management in using nitrogen in different conditions of soil moisture is one of the most important farming issues which has considerable effects on the growth indices of sunflower, so that by choosing the right amount of nitrogen and appropriate management during its distribution in relation to various moisture conditions, it is possible to achieve a balanced combination of growth indices in plant community (Mojaddam et al., 2012). This research is conducted with regard to the current challenges in the region in terms of using nitrogen and lack of proper management during its consumption and it tries to study the interaction effect of this factor and water stress on physiological indices of growth, as well as intends to offer a way for proper utilization of nitrogen and water.

\section{MATERIALS AND METHODS}

This research was conducted in Omidiye-Iran (latitude: $49^{\circ} 41^{\prime}$; longitude: $30^{\circ} 44^{\prime}$; altitude: 27 meters) with hot and dry climate. The average temperature of the coldest and the hottest month of the year and precipitation are $-2{ }^{\circ} \mathrm{C}, 52^{\circ} \mathrm{C}$ and $274 \mathrm{~mm}$ per year. The experiment location had a sandy loam soil with Ec of $4.2 \mathrm{dS} /$ $\mathrm{m}$ and $\mathrm{pH}$ of 7.6 . The soil organic matter was $0.7 \%$ and the amount of nitrogen, potassium, and phosphorus was 5.2 (poor), 108 (rich), 63 (good) parts per million, respectively. The sunflower hybrid used in the study was Iroflor that is bred by Plant Breed Institute of Iran. The experiment was carried out based on randomized complete block design with split-plot arrangement in 3 replicates. Irrigation treatment was considered as the main factor and the nitrogen top-dressing pattern as the sub-factor. Irrigation treatment was performed at three levels: optimum irrigation $\left(\mathrm{I}_{0}\right)$, exercising water stress from eight-leaf stage until head appearance $\left(\mathrm{I}_{\mathrm{V}}\right)$ and exercising water stress from head appearance to maturity. In moderately irrigated $\left(\mathrm{I}_{0}\right)$ and water stressed plots, irrigation was done after 50 and $120 \mathrm{~mm}$ evaporation from class A pan, respectively. Soil moisture was $25 \%$ and $75 \%$ of the available soil water content $(\mathrm{FC}-\mathrm{WP})$ in moderate irrigated $\left(\mathrm{I}_{0}\right)$ and water stress plots, respectively. In all three levels of nitrogen top-dressing pattern, $120 \mathrm{~kg}$ nitrogen per hectare was equally used but in different stages of plant growth: at the first level, $25 \%$ nitrogen was applied in the planting stage, $50 \%$ in the eight-leaf stage, and $25 \%$ in the head appearing stage; at the second level, $50 \%$ nitrogen was applied in the eightleaf stage, and $50 \%$ in the head appearing stage, and at the third level, 50\% nitrogen was used in the planting stage and $50 \%$ in the head appearing stage. Experimental 
plots had eight planting rows as long as 6 meters and a distance of $75 \mathrm{~cm}$ between rows. The distance between the bushes on planting lines was $15 \mathrm{~cm}$ after thinning and the depth of planting was $3 \mathrm{~cm}$. The density of 9 plants per square meter was considered. At the end of the growing season, the amount of yield and its components was measured by the surface harvest of 1 meter area on 6 central rows of each plot. In this research 5 samples were totally taken. The first sample was taken 21 days after planting and it was repeated in 14-day intervals that are 35, 49, 63, and 85 days after planting. In each sample, 30 plants were harvested on 6 central rows of each plot. The samples were separated into leaves, stems, and heads. After measuring the leaf area, samples were placed in a $72^{\circ} \mathrm{C}$ oven for 48 hours and were weighed after they dried. To calculate the components of growth analysis the following formulas were applied respectively:

Net Assimilation Rate: $C G R=N A R \times L A I \Rightarrow N A R=\frac{C G R}{L A I}$

Crop Growth Rate: $\quad C G R=\frac{W_{2}-W_{1}}{t_{2}-t_{1}} \times \frac{1}{G A}$
Where:

$\mathrm{GA}=$ Ground Area;

$\mathrm{T}=$ time;

$\mathrm{w}_{1}$ and $\mathrm{w}_{2}=$ dry weight of primary and secondary sample, respectively.

Data analysis was carried out by SAS software and by drawing diagrams with Excel and the means were compared by Duncan's multiple range tests at $5 \%$ level.

\section{RESULTS}

\section{Irrigation}

$I_{V}$ and $I_{R}$ caused a significant reduction of grain yield (2011: 13.1 and 8.6\%; 2012: 16.7 and 30.5\%) and total biomass at maturity (2011: 25.3 and $27.1 \%$; 2012: 26.4 and 28.9\%) and increase of harvest index (2011: 14.0 and 20.0\%; 2012: 11.9 and $13.4 \%$ ) in comparison to $\mathrm{I}_{0}$ (Table 3 ), the effect of year $\times$ irrigation was not significant for these two traits (Table 1).

Table 1: The mean squares of ANOVA for grain yield (GY), total biomass at maturity (TB), grains per head (GPH), 100 grain weight (GW) and harvest index (HI) in combined analysis of 2010 and 2011 data

\begin{tabular}{lcccccc}
\hline S.O.V & DF & GY & TB & GPH & GW & HI \\
\hline$Y$ & 1 & NS & NS & NS & NS & NS \\
$W$ & 2 & $* *$ & $* *$ & NS & $* *$ & $* *$ \\
YW & 2 & NS & NS & NS & NS & NS \\
N & 2 & $* *$ & $* *$ & $* *$ & NS & $*$ \\
$W N$ & 4 & $*$ & $*$ & NS & $*$ & NS \\
YN & 2 & $* *$ & $* *$ & $* *$ & NS & $*$ \\
YWN & 4 & NS & NS & NS & NS & NS \\
\hline
\end{tabular}

(Note: $Y$-year effect; $W$-water regime effect; $N$-nitrogen dividing pattern). 


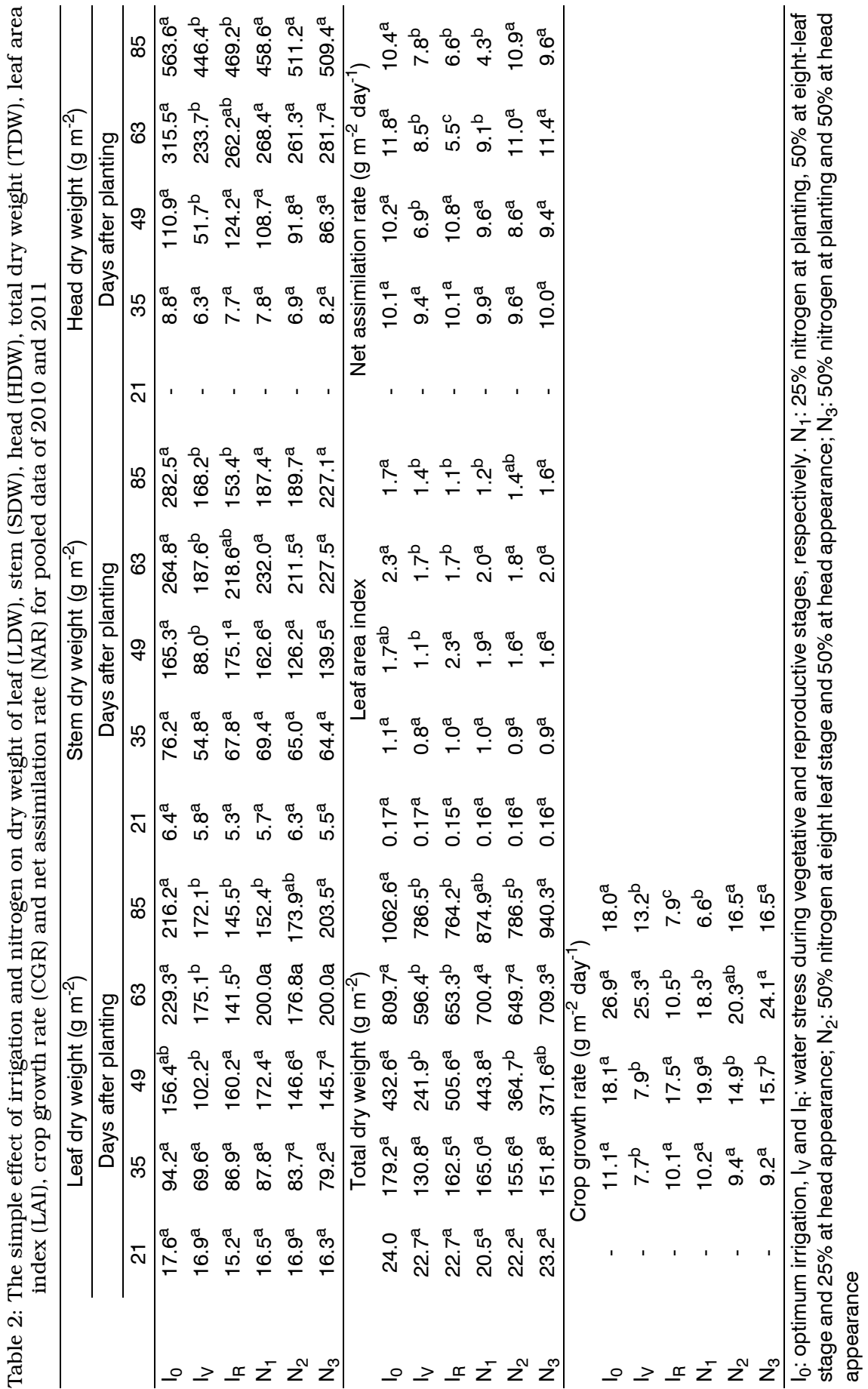


The number of grains per head was not affected by irrigation regimes in both years, while $I_{V}$ and $I_{R}$ caused a significant reduction of 100 grain weight from 7.0 to $6.5 \mathrm{~g}$ (Table 3).

Table 3: The simple effect of irrigation and nitrogen on grain yield (GY), grains per head $(\mathrm{GPH})$, grain weight $(\mathrm{GW})$, harvest index (HI) and biomass at maturity (BM) for separate data of 2010 and 2011

\begin{tabular}{|c|c|c|c|c|c|c|c|c|c|c|}
\hline & \multirow{2}{*}{\multicolumn{2}{|c|}{$\frac{\text { Grain yield }}{\text { GY }\left(\mathrm{g} \mathrm{m}^{-2}\right)}$}} & \multirow{2}{*}{\multicolumn{2}{|c|}{$\frac{\text { Grains per head }}{\text { GPH }}$}} & \multirow{2}{*}{\multicolumn{2}{|c|}{$\frac{100 \text { Grain weight }}{\text { GW (g) }}$}} & \multirow{2}{*}{\multicolumn{2}{|c|}{$\frac{\text { Harvest index }}{\mathrm{HI}(\%)}$}} & \multirow{2}{*}{\multicolumn{2}{|c|}{$\frac{\text { Biomass at maturity }}{\mathrm{BM}\left(\mathrm{g} \mathrm{m}^{-2}\right)}$}} \\
\hline & & & & & & & & & & \\
\hline & 2011 & 2012 & 2011 & 2012 & 2011 & 2012 & 2011 & 2012 & 2011 & 2012 \\
\hline $\mathrm{I}_{0}$ & $267^{a}$ & 311 & $536.0^{\mathrm{a}}$ & $521.2^{\mathrm{a}}$ & $7.0^{\mathrm{a}}$ & $7.1^{\mathrm{a}}$ & $25.1^{\mathrm{b}}$ & $24.4^{b}$ & $1062^{a}$ & $1061^{a}$ \\
\hline $\mathrm{IV}_{\mathrm{V}}$ & $232^{\mathrm{b}}$ & $259^{a}$ & $493.5^{a}$ & $467.5^{\mathrm{a}}$ & $6.6^{\mathrm{b}}$ & $6.6^{\mathrm{b}}$ & $29.2^{\mathrm{ab}}$ & $27.7^{\mathrm{a}}$ & $794^{\mathrm{b}}$ & $778^{b}$ \\
\hline$I_{R}$ & $244^{b}$ & $216^{b}$ & $526.1^{\mathrm{a}}$ & $468.2^{\mathrm{a}}$ & $6.5^{\mathrm{b}}$ & $6.5^{\mathrm{b}}$ & $31.5^{\mathrm{a}}$ & $28.2^{\mathrm{a}}$ & $774^{b}$ & $754^{b}$ \\
\hline $\mathrm{N}_{1}$ & $240^{\mathrm{b}}$ & $213^{b}$ & $497.0^{\mathrm{a}}$ & $478.1^{a}$ & $6.8^{\mathrm{a}}$ & $7.2^{\mathrm{a}}$ & $30.0^{a}$ & $25.5^{\mathrm{a}}$ & $800^{b}$ & $942^{\mathrm{a}}$ \\
\hline $\mathrm{N}_{2}$ & $301^{a}$ & $241^{a}$ & $560.2^{\mathrm{a}}$ & $376.5^{b}$ & $6.5^{\mathrm{a}}$ & $6.9^{a}$ & $29.5^{a}$ & $32.9^{a}$ & $1020^{a}$ & $552^{\mathrm{b}}$ \\
\hline $\mathrm{N}_{3}$ & $237^{b}$ & $182^{b}$ & $498.4^{\mathrm{a}}$ & $506.1^{a}$ & $6.8^{\mathrm{a}}$ & $7.0^{\mathrm{a}}$ & $26.4^{\mathrm{a}}$ & $25.0^{\mathrm{b}}$ & $897^{b}$ & $991^{a}$ \\
\hline
\end{tabular}

$\mathrm{I}_{0}$ : optimum irrigation, $\mathrm{I}_{\mathrm{V}}$ and $\mathrm{I}_{\mathrm{R}}$ : water stress during vegetative and reproductive stages, respectively. $\mathrm{N}_{1}: 25 \%$ nitrogen at planting, $50 \%$ at eight-leaf stage and $25 \%$ at head appearance;

$\mathrm{N}_{2}: 50 \%$ nitrogen at eight leaf stage and $50 \%$ at head appearance;

$\mathrm{N}_{3}: 50 \%$ nitrogen at planting and $50 \%$ at head appearance

Dry weight of leaf (LDW) and stem (SDW) during the growth period was significantly affected by irrigation (Table 2). LDW and SDW was the same in all three levels of irrigation until about 35 days after planting (Figures 1 and 2), because $I_{V}$ was exercised 28 days after planting. In $35^{\text {th }}$ day after planting, the difference between irrigation levels gradually increased (Figures 1 and 2), so that there was a significant difference between irrigation treatments in terms of LDW and SDW since one week after exercising the $\mathrm{I}_{\mathrm{V}}$ until the maturity (Table 2). Average cross years, exercising $I_{V}$ and $I_{R}$ led to significant decrease of final dry weight of leaf (20.4 and $32.7 \%$ ), stem ( 40.5 and $45.7 \%$ ), head (20.8 and $16.7 \%$ ), total weight (26.0 and $28.1 \%)$, leaf area index (17,6 and $35.3 \%$ ) and grain yield (15.0 and $20.4 \%$ ) in comparison to $I_{0}$ and there was no difference between $I_{R}$ and $I_{V}$ in terms of these traits expect for leaf area index (Table 2). $\mathrm{I}_{\mathrm{R}}$ was exercised concurrent with the third sampling 49 days after planting. $\mathrm{I}_{\mathrm{V}}$ caused a slower trend of weight increase of stem and leaf in comparison to $\mathrm{I}_{0}$, while $\mathrm{I}_{\mathrm{R}}$ caused a rapid decrease of SDW and LDW at 49 and 63 days after planting, respectively (Figures 1,2). The head appeared 35 days after planting and there was a slow increase of weight in all three levels of irrigation until 49 days after planting (Figure 3). Changes of total dry weight (TDW) in early stages of growth were very few and there was no significant difference between irrigation levels (Figure 4). The highest crop growth rate (CGR) within 63 days of planting belonged to the $I_{0}$ (Figure 8 ). In $I_{R}$ and $I_{V}$ the CGR considerably decreased (Table 2). The net absorption rate (NAR) decreased in drought stress and in final stage 85 days after planting (Figure 9 ); the highest reduction was related to $I_{R}$ which was not significantly different from $\mathrm{I}_{\mathrm{V}}$ (Table 2 ). 


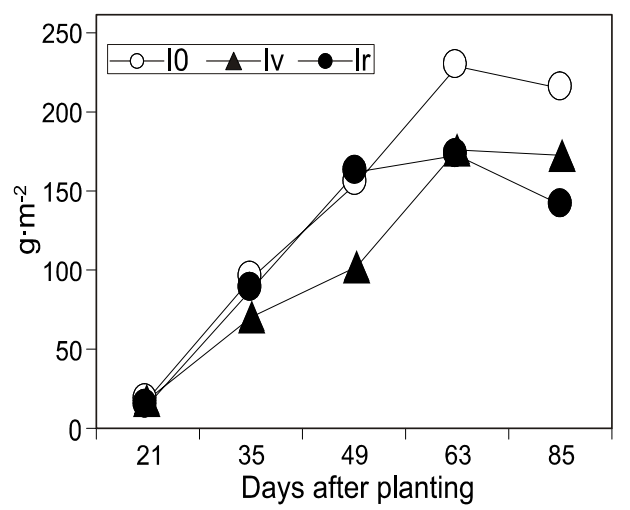

Figure 1: The effect of irrigation (I) on sunflower dry weight of leaf (LDW) (pooled data of 2011 and 2012)

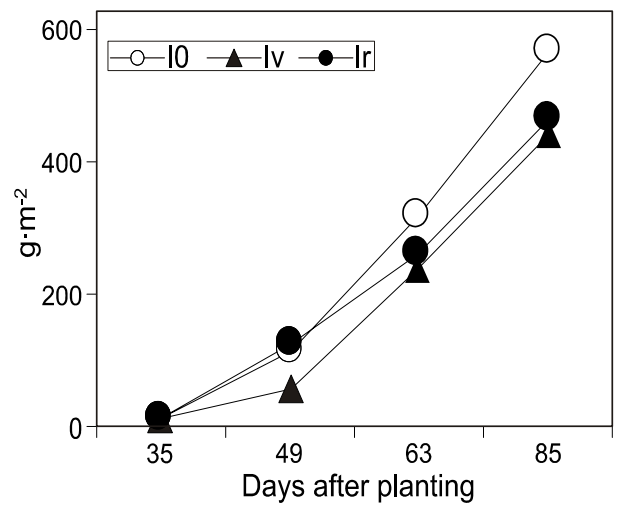

Figure 3: The effect of irrigation (I) on sunflower dry weight of head (HDW) (pooled data of 2011 and 2012)

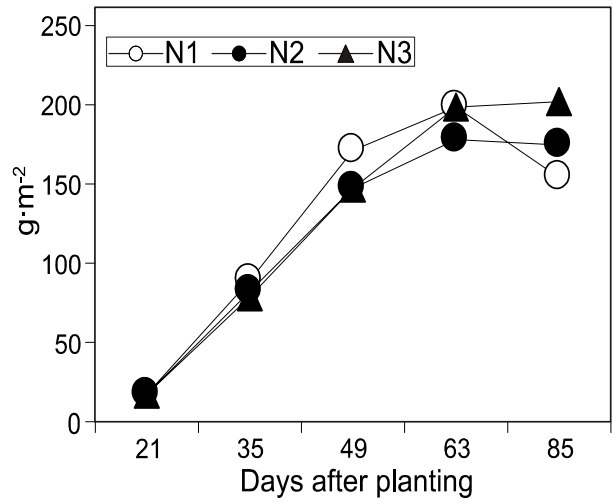

Figure 5: The effect of nitrogen $(N)$ on sunflower dry weight of leaf (LDW) (pooled data of 2011 and 2012)

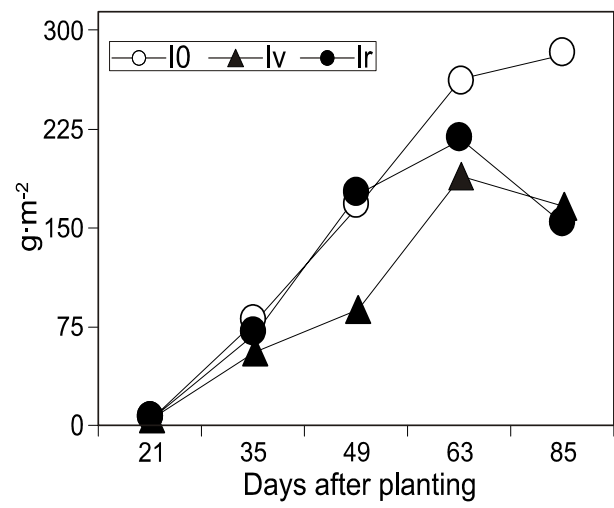

Figure 2: The effect of irrigation (I) on sunflower dry weight of stem (SDW) (pooled data of 2011 and 2012)

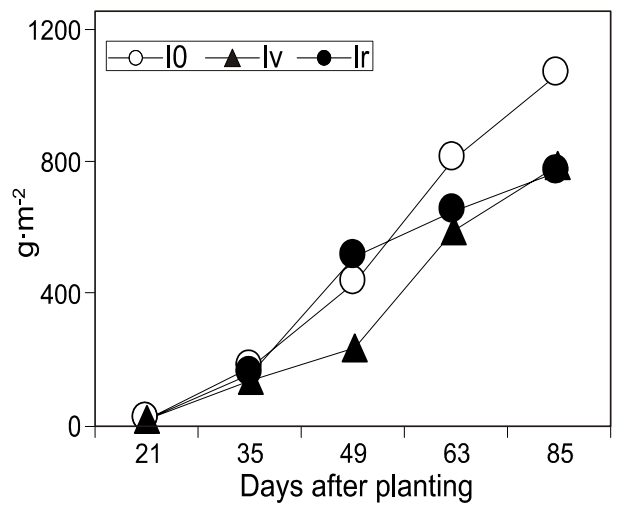

Figure 4: The effect of irrigation (I) on sunflower total dry weight (TDW) (pooled data of 2011 and 2012)

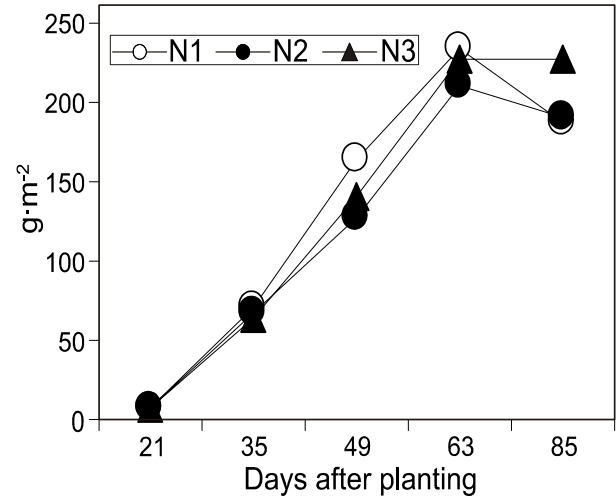

Figure 6: The effect of nitrogen $(N)$ on sunflower dry weight of stem (SDW) (pooled data of 2011 and 2012) 


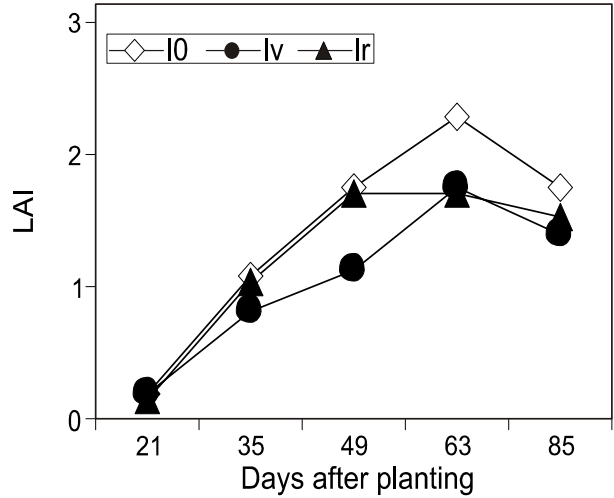

Figure 7: The effect of irrigation (I) on sunflower leaf area index (LAI) (pooled data of 2011 and 2012)

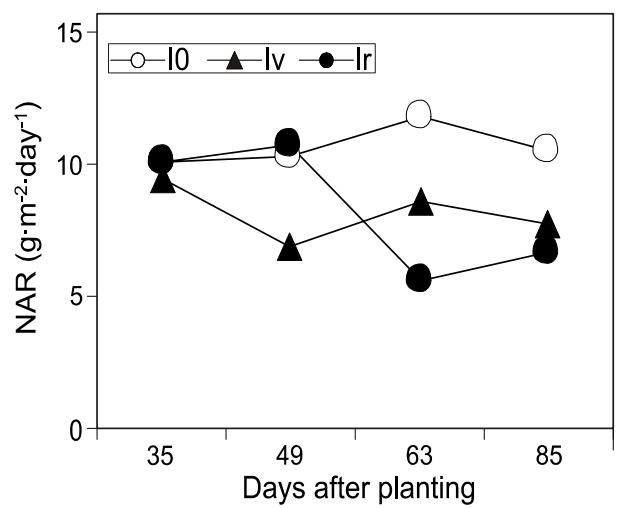

Figure 9: The effect of irrigation (I) on sunflower net assimilation rate (NAR) (pooled data of 2011 and 2012)

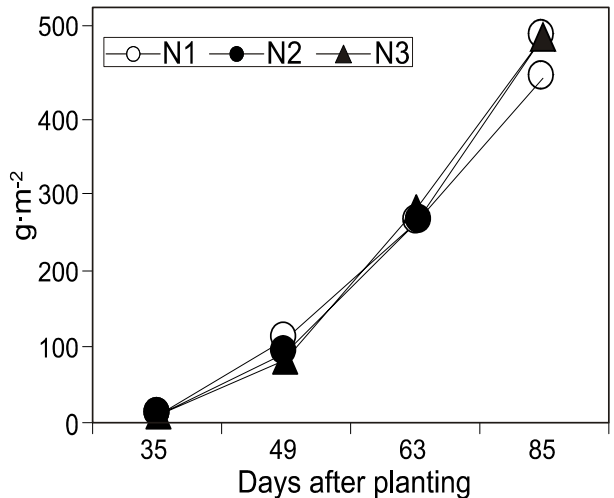

Figure 11:The effect of nitrogen $(N)$ on sunflower dry weight of head (HDW) (pooled data of 2011 and 2012)

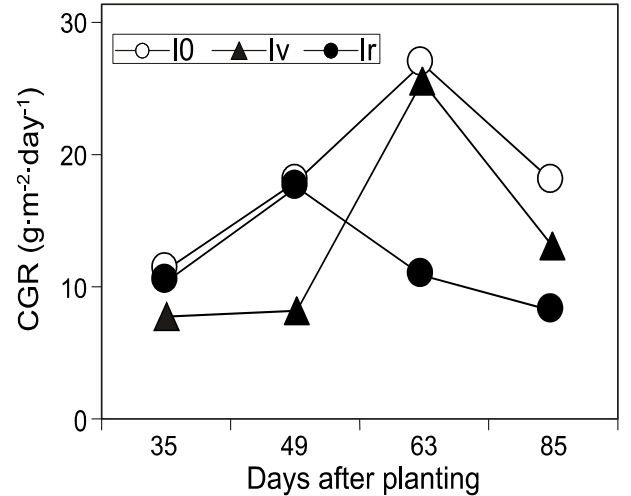

Figure 8: The effect of irrigation (I) on sunflower crop growth rate (CGR) (pooled data of 2011 and 2012)

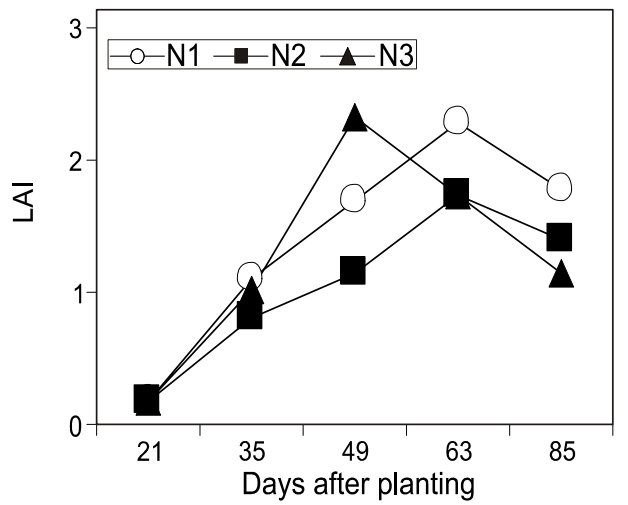

Figure 10:The effect of nitrogen (N) on sunflower leaf area index (LAI) (pooled data of 2011 and 2012)

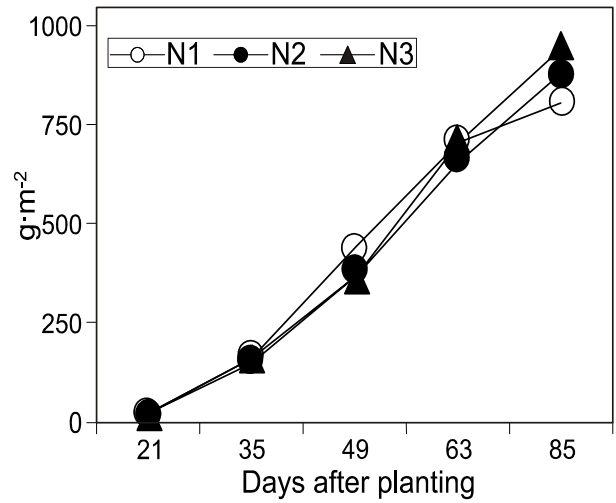

Figure 12:The effect of nitrogen $(N)$ on sunflower total dry weight (TDW) (pooled data of 2011 and 2012) 


\section{Nitrogen}

The curve of LDW and SDW during the growth season shows that in fertilizer treatments the rate of weight increase is very slow in early stages then goes upward and increases, so that the maximum amount of LDW and SDW is obtained 63 days after planting (Figures 5,6), but then the photosynthetic matters in leaf and stem move towards the grain and head because of the quick growth of grain and the accumulation of dry matter in head increases (Figure 11), which consequently increases the TDM (Figure 12). The effect of nitrogen top-dressing pattern on LDW and TDW was significant only 85 days after planting (Table 2). Average cross years, $\mathrm{N}_{1}$ caused a significant reduction of the TDW and the LDW as much as $25.1 \%$ and $15.1 \%$, respectively in comparison to $\mathrm{N}_{3}$ (Table 2 ). However, the grain yield did not significantly change compared to $\mathrm{N}_{3}$ in both years (Table 3 ). The effect of nitrogen division and its interaction with the year was significant (Table 1). In 2010, $\mathrm{N}_{2}$ resulted to 20.0 and $27.0 \%$ higher grain yield (GY) and 21.5 and $12 \%$ higher total biomass at maturity (TB) compared to $\mathrm{N}_{1}$ and $\mathrm{N}_{2}$ (Table 3). However, in 2011, $\mathrm{N}_{2}$ had significantly lower GY and TB compared to $\mathrm{N}_{3}$ and $\mathrm{N}_{1}$ (Table 3 ). It could be due to low $\mathrm{N}$ content of the soil at the beginning of the second growing season and lack of nitrogen application in this treatment during planting. Nitrogen top-dressing pattern did not have a significant effect on the SDW and HDW even until the end of growing season (Figures 6 and 11). However, $\mathrm{N}_{3}$ treatment which had not consumed nitrogen in 8 leaf stage had $20 \%$ lighter dry weight than $\mathrm{N}_{1}$ treatment which had consumed $50 \%$ nitrogen in this stage (Table 2). In $\mathrm{N}_{2}$, nitrogen was not used in planting stage and in spite of using nitrogen in 28 (8 leaf) and 49 days after planting ( 14 days after head appearing), the increase of LDW from 49 days after planting until the end of growing season was less than that of two other nitrogen treatments which had received nitrogen in planting stage (Figure 5). In $\mathrm{N}_{3}$ treatment, lack of nitrogen in the 8-leaf stage did not reduce the increase of LDW (Figure 5). In $\mathrm{N}_{1}$ treatment, which had a lighter LDW at the end of growing season, HDW was also lighter than other nitrogen treatments (Figures 5, 11). The leaf area index was the same in all three levels of nitrogen until 21 days after greening, because nitrogen top-dressing pattern was used 10 days after planting and the fertilizers did not have enough time to affect it, gradually the difference among fertilizer levels increased (Figure 10). LAI was significantly affected by fertilizer treatment in the final stage while the grain yield was not affected significantly (Tables 1,2 ). $\mathrm{N}_{1}$ top-dressing pattern caused a significant $25 \%$ reduction of final LAI in comparison to $\mathrm{N}_{3}$ (Table 2). Although there was not a significant difference between $\mathrm{N}_{2}$ and $\mathrm{N}_{3}$ treatments in terms of their effect on LAI (Table 2). CGR in $\mathrm{N}_{2}$ and $\mathrm{N}_{3}$ in final stage 85 days after planting stage was more than that of $\mathrm{N}_{1}$ which can be interpreted as the superiority of accumulation of dry matter and greater LAI in $\mathrm{N}_{2}$ and $\mathrm{N}_{3}$ treatments (Table 2; Figures 10 and 13). The changes of net absorption rate during the growing season were affected by fertilizer treatments (Figure 14). At maturity, the highest decrease 
of net absorption rate was related to $\mathrm{N}_{1}$ and there was not much difference between $\mathrm{N}_{2}$ and $\mathrm{N}_{3}$ (Table 2).

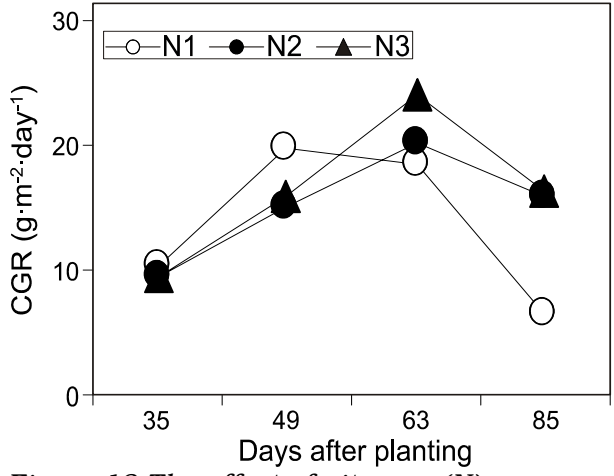

Figure 13:The effect of nitrogen $(N)$ on sunflower crop growth rate (CGR) (pooled data of 2011 and 2012)

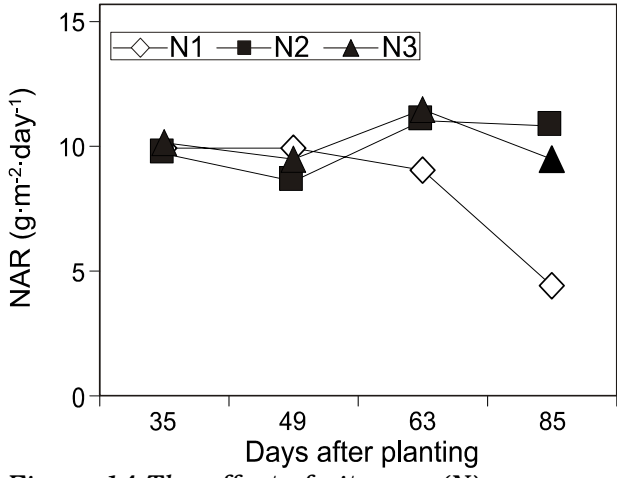

Figure 14:The effect of nitrogen $(N)$ on sunflower net assimilation rate (NAR) (pooled data of 2011 and 2012)

\section{Irrigation $\times$ Nitrogen}

LDW, SDW and TDW and LAI and GY were affected by irrigation and nitrogen interaction (Table 4). In $\mathrm{I}_{0}, \mathrm{~N}_{3}$ caused a significant $34.8 \%$ increase of LDW and an insignificant increase of SDW and TDW as much as $30.9 \%$ and $16.3 \%$ respectively and also a significant $27.1 \%$ reduction of the grain yield in comparison to $\mathrm{N}_{2}$ (Table 4). In $\mathrm{I}_{\mathrm{V}}, \mathrm{N}_{1}$ significantly decreased the LDW (43.7 and 40.4\%), SDW (38.5 and $44.1 \%$ ), and TDW (28.6 and $29.9 \%$ ) and insignificantly decreased the grain yield as much as 12 and $13 \%$ in comparison to $\mathrm{N}_{2}$ and $\mathrm{N}_{3}$, respectively (Table 4 ). $\mathrm{N}_{2}$ and $\mathrm{N}_{3}$ treatments did not have any significant differences statistically (Table 4 ). In $\mathrm{I}_{R}$, nitrogen top-dressing pattern had no effect on LDW, SDW, TDW and grain yield (Table 4).

Table 4: The interaction effect of irrigation and nitrogen on dry weight of leaf (LDW), stem (SDW), head (HDW), total dry weight (TDW) at maturity and grain yield (GY) for pooled data of 2011 and 2012

\begin{tabular}{ccccccc}
\hline & & LDW & SDW & HDW & TDW & GY (Mean) \\
\cline { 3 - 6 } & & $\left(\mathrm{g} \mathrm{m}^{-2}\right)$ & $\left(\mathrm{g} \mathrm{m}^{-2}\right)$ & $\left(\mathrm{g} \mathrm{m}^{-2}\right)$ & $\left(\mathrm{g} \mathrm{m}^{-2}\right)$ & $\left(\mathrm{g} \mathrm{m}^{-2}\right)$ \\
\hline $\mathrm{T}_{0}$ & $\mathrm{~N}_{1}$ & $200.6^{\mathrm{ab}}$ & $287.7^{\mathrm{a}}$ & $553.7^{\mathrm{a}}$ & $800.0^{\mathrm{a}}$ & $279.4^{\mathrm{a}}$ \\
& $\mathrm{N}_{2}$ & $176.5^{\mathrm{b}}$ & $228.6^{\mathrm{a}}$ & $572.4^{\mathrm{a}}$ & $738.7^{\mathrm{a}}$ & $280.7^{\mathrm{a}}$ \\
& $\mathrm{N}_{3}$ & $271.4^{\mathrm{a}}$ & $331.3^{\mathrm{a}}$ & $564.6^{\mathrm{a}}$ & $890.7^{\mathrm{a}}$ & $204.6^{\mathrm{b}}$ \\
\hline $\mathrm{I} \mathrm{V}$ & $\mathrm{N}_{1}$ & $115.8^{\mathrm{b}}$ & $114.3^{\mathrm{b}}$ & $387.3^{\mathrm{a}}$ & $626.6^{\mathrm{a}}$ & $204.1^{\mathrm{a}}$ \\
& $\mathrm{N}_{2}$ & $206.1^{\mathrm{a}}$ & $185.8^{\mathrm{a}}$ & $471.3^{\mathrm{a}}$ & $501.3^{\mathrm{b}}$ & $237.8^{\mathrm{a}}$ \\
& $\mathrm{N}_{3}$ & $194.4^{\mathrm{a}}$ & $204.5^{\mathrm{a}}$ & $480.6^{\mathrm{a}}$ & $661.3^{\mathrm{a}}$ & $232.2^{\mathrm{a}}$ \\
\hline $\mathrm{I}_{\mathrm{R}}$ & $\mathrm{N}_{1}$ & $140.7^{\mathrm{a}}$ & $160.2^{\mathrm{a}}$ & $434.7^{\mathrm{a}}$ & $674.7^{\mathrm{a}}$ & $228.3^{\mathrm{a}}$ \\
& $\mathrm{N}_{2}$ & $139.2^{\mathrm{a}}$ & $154.7^{\mathrm{a}}$ & $489.9^{\mathrm{a}}$ & $709.3^{\mathrm{a}}$ & $243.2^{\mathrm{a}}$ \\
& $\mathrm{N}_{3}$ & $144.6^{\mathrm{a}}$ & $145.4^{\mathrm{a}}$ & $482.9^{\mathrm{a}}$ & $576.0^{\mathrm{b}}$ & $250.3^{\mathrm{a}}$ \\
\hline
\end{tabular}

$\mathrm{I}_{0}$ : optimum irrigation, $\mathrm{I}_{\mathrm{V}}$ and $\mathrm{I}_{\mathrm{R}}$ : water stress during vegetative and reproductive stages, respectively. $\mathrm{N}_{1}: 25 \%$ nitrogen at planting, $50 \%$ at eight-leaf stage and $25 \%$ at head appearance;

$\mathrm{N}_{2}: 50 \%$ nitrogen at eight leaf stage and $50 \%$ at head appearance;

$\mathrm{N}_{3}: 50 \%$ nitrogen at planting and $50 \%$ at head appearance 


\section{DISCUSSION}

The increase of vegetative and reproductive growth increased the dry weight in $I_{O}$ (Table 1), while the decrease of LAI and NAR decreased the dry substance in $I_{R}$ and $I_{V}$ which consequently resulted in reduction of grain yield (Figures 7,9 ). In $I_{R}$ and $I_{V}$, variation of CGR was affected by variation of LAI and NAR, but variation of CGR in nitrogen levels was affected by variation of LAI. This is also reported by Mojaddam et al. (2012).

Results from the $\mathrm{I}_{0} \mathrm{~N}_{3}$ treatment sounds that in $\mathrm{I}_{0}$, the consumption of $50 \%$ of nitrogen in planting stage has increased the vegetative growth and production of dry matter which has disrupted the reproductive growth and transmission of photosynthetic materials of the grains. Ozer et al. (2004) and Oyinlola et al. (2010) reported that high $\mathrm{N}$ availability may shift the balance between vegetative and reproductive growth toward excessive vegetative development, thus delaying crop maturity and reducing seed yield.

In $\mathrm{N}_{1}$ top-dressing pattern when the plant faced drought stress, the lack of water reduced the absorption of nitrogen and its transmission to photosynthetic organs and also decreased the assimilate and thus decreased the production of shoots (Hu et al., 2009; Gholinezhad et al., 2009), which in turn led to the decrease of biomass and the grain yield (Table 4). In $\mathrm{I}_{\mathrm{v}} \mathrm{N}_{2}$ treatment, the use of nitrogen in 8-leaf stage and when the plant faced drought stress disrupted the absorption of nitrogen by the plant and slowed down the increase of LAI rapidly. Considering the direct relation which is reported between the leaf index and the grain yield (Mojaddam et al., 2012), it could be stated that by the reduction of LAI, HDM and the grain yield have decreased in this treatment (Table 4). The limits of nitrogen absorption and the reduction of positive effects of using nitrogen during the decrease of soil moisture have been reported by other researchers (Gholinezhad et al., 2009). On the whole, $\mathrm{N}_{2}$ treatment in different irrigation regimes caused more increase of grain yield, but $\mathrm{N}_{3}$ in $\mathrm{I}_{0}$ and $\mathrm{N}_{1}$ treatment in $\mathrm{I}_{\mathrm{R}}$ and $\mathrm{I}_{\mathrm{V}}$ irrigations are not recommended.

\section{REFERENCES:}

Gholinezhad, E., Aynaband, A., Hassanzade-Ghorthapeh, A., Noormohamadi, Gh., Bernousi, I., 2009. Study the effect of drought stress on yield, yield components and harvest index of sunflower hybrid Iroflor at different levels of nitrogen and plant population. Notulae Botanicae Horti Agrobotanici Cluj-Napoca, 37(2): 85-94.

Hu, T., Kang, S., Li, F., Zhang, J., 2009. Effects of partial root-zone irrigation on the nitrogen absorption and utilization of maize. Agricultural Water Management 96: 208-214.

Hussain, S., Ma, B.L., Saleem, M.F., Anjum, S.A., Saeed, A., Iqbal, J., 2012. Abscisic acid spray on sunflower acts differently under drought and irrigation conditions. Agronomy Journal 104(3): 561-568.

Jalalian, J., Modarres-Sanavy, S.A.M., Saberali, S.F., Sadat-Asilan, K., 2012. Effetcs of the combination of beneficial microbes and nitrogen on sunflower seeed yields and seed quality traits under different irrigation. Field Crops Research 152: 26-34. 
Mojaddam, M., Shokuhfar, A., Lack, Sh., 2012. Effects of water stress and different levels of nitrogen on growth analysis parameters of sunflower. Journal of Food, Agriculture and Environment 10(1): 839-842.

Oyinlola, E.Y., Ogunwole, J.O. and Amapu, I.Y., 2010. Response of sunflower (Helianthus annuus L.) to nitrogen application in a savanna alfisol. Helia 33(52): 115-126.

Ozer, H., Polat, T., Ozturk, E., 2004. Response of irrigated sunflower hybrids to nitrogen fertilization: growth, yield and yield components. Plant, Soil and Environment 50(4): 205211.

Parmar, N.G., Chanda, S.V., 2002. Growth analysis using curve fitting method in early and late sown sunflower. Plant Breeding and Seed Science 46(1): 61-69.

Pejić, B., Maksimović, L., Škorić, D., Milić, S., Stričević, R., Cupina, B., 2009. Effect of water stress on yield and evapotranspiration of sunflower. Helia 32(51): 19-32. 
